\title{
Excerpts of the History of the Development of the Musical Education in Russia: L.M. Rudolf and His Role in the Establishment of the Saratov Conservatory
}

\author{
Lilia Vishnevskaya ${ }^{1,{ }^{*}}$ Natalia Ivanova ${ }^{1, a}$ Elena Ponomareva ${ }^{1, b}$
}

\author{
${ }^{1}$ The Music Theory and Composition Department of the Saratov State L.V. Sobinov Conservatory, Saratov, Russia \\ aEmail: nvi0909@gmail.com \\ bEmail: elepon@mail.ru \\ *Corresponding author. Email: liliya-vishnevskaya@yandex.ru
}

\begin{abstract}
One of the first professors of the Saratov Conservatory was L.M. Rudolf, a talented composer and musicologist, a student of S.I. Taneyev. His active pedagogical, researching, musical and social activities laid the groundwork for the development of the professional musical education in Saratov. He taught several generations of gifted musicians of different specialties, formed the core principles for the work of the music theory and composition department. His scientific and pedagogical works - for instance "The Manual for the Analysis of Musical forms", "Harmony textbook"- are of great interest. Many prominent musician were L.M. Rudolf's students, such as Russian composers and musicologists Y.V. Kochurov, V.V. Pushkov, K.Y. Listov, Y.S. Soloduho I.V. Sposobin, S.B. Maksimov, A.N. Dmitriev, V.P. Shokin, S.I. Levit, L.L. Kristiansen, I.A. Tyutmanov, Y.K. Evdokimov, Azerbaijan composers K. Karayev, Z. Gadzhibekov, T. Kuliyev, S. Rustamov and many others.
\end{abstract}

Keywords: musical education, L.M. Rudolf, Saratov Conservatory, music theory

\section{INTRODUCTION}

The Saratov State L.V. Sobinov Conservatory is one of the oldest in Russia. It was founded in 1912 as the third conservatory in Russia after Saint Petersburg and Moscow. The department of music theory and composition was among the first ones and was started by L.M. Rudolf and G.E. Conus, both graduates of the Moscow Conservatory and students of S.I. Taneyev. Both were talented composers, theorists and experienced teachers. Their active pedagogical, scientifical, musical, social, composing and performing ${ }^{1}$ activity initiated the development of the professional musical education in Saratov and contributed to the stepping up of the cultural life in the city in general. Especially big was the role of L.M. Rudolf who brought up several generations of gifted musicians. ${ }^{2}$

L.M. Rudolf and G.E. Conus acted often as conductors of the symphony orchestra.

G.E. Conus was a professor of the Saratov Conservatory until 1920, and after the revolution 1917 was even its director for a year and a half, but after that returned to Moscow and continued working at the Moscow conservatory.

\section{THE BIOGRAPHY OF L.M. RUDOLF}

Leopold Moricevich Rudolf was born on 21 June $^{3}$ 1877 in Riga. His first musical teacher was his father, Moric Rudolf ${ }^{4}$ who was a musical critic and teacher of musical theory. And although the lessons began quite late when Leopold was about 16 years old, he got a solid initial musical education at home, which allowed him to enter the Moscow Conservatory in 1897. At the conservatory, L.M. Rudolf attended composition classes by M.M. Ippolitov-Ivanov and theoretical classes (counterpoint, fugue, form analysis) by S.I. Taneyev. According to his contemporaries, he was among the Taneyev's favourite students. His course mates were L.V. Nikolaev and R.M. Glier. After graduation from the Moscow Conservatory with honours in 1901, the young composer worked in Moscow for a while, and in 1903 he got, on the recommendation of V.I. Safonov, an invitation to work as a teacher of theoretical musical subjects in the Saratov Musical Academy by the Russian Musical Society. 1912 he became one of the first professors of the newly opened Saratov Alexey Conservatory. His

According to other sources 31 August 1877

M. Rudolf was an author of a big musical dictionary that held the "data on composers, musical institutions, particular pieces etc." [1]. 
energetic and versatile professional activity made up a whole epoch in the life of the conservatory and laid the foundation for the establishment of the Saratov musicology and composition school. In1930, L.M. Rudolf had to leave Saratov for reasons beyond his control. In 1930 - 1932 he worked at the "rabfak"', or workers faculty, by the Leningrad Conservatory and musical academies in Leningrad. In 1932 he moved to Baku where he became the head of the music theory department of the Azerbaijan Conservatory and the chief editor of a musical publishing house. The diverse talent of Rudolf was revealed in that period very vividly. He finished and published his research and methodological works "Harmony text and task book", "Piano Harmony Exercises". In a short time he mastered Azerbaijan language so well that he even compiled his own Russian-Azerbaijan dictionary that included 20000 words. He studied and arranged Azerbaijan folk songs and made an instrumentation (together with R.M. Glier) of the opera "Nargiz" by M. Magomayev. Among the students of Rudolf in the Baku Conservatory were the most famous Azerbaijan composers - K. Karayev, Z. Gadzhibekov, T. Kuliyev, S. Rustamov. L.M. Rudolf died 21 April 1938 in Baku.

\section{L M. RUDOLPH'S PEDAGOGICAL, MUSICAL AND SOCIAL ACTIVITIES IN SARATOV}

L.M. Rudolph came to Saratov in 1903. That was time of a noticeable animation of the musical life in Saratov, and the professional music education was in the making. On the initiative of its director S.K. Eksner, talented and highly qualified teachers were invited to work at the Saratov Musical Academy (and later at the conservatory): Pianists A.P. Rahmanov and I.A. Rosenberg, brothers Y.Y. and E.Y. Gayek (a violinist and pianist), a violinist V.V. Zayts, cellists M.Y. Gordel, S.M. Kozolupov, a trumpeter V.G. Brandt, singers M.E. Medvedev and Eichenwald-Dubrovskaya, a prominent theorists G.E. Conus. L.M. Rudolf was one of them. The musical academy thanks to the enthusiasm of S.K. Eksner got a new building, especially built in the center of the city. The academy had over 600 students and was steadily developing towards becoming a conservatory. A young talented composer took a worthy place there and got actively involved not only in teaching, but also in performing. He taught theoretical subjects, composition and piano. He often took part in a concert as a choir conductor or a concertmaster accompanying singers, and of course, he was the author of many pieces performed. The newspapers of that time often contain reviews of those performances ${ }^{5}$.

Numerous references to the concert performances by L. M. Rudolph are found in the monograph of V.E. Hanetskij about the history of musical life in Saratov at the beginning of the XX century [2].
L.M. Rudolf's teaching activity was of great importance for the improvement of the training level of all the students of the musical academy, regardless their specialty. At the same time, it marked the beginning of a true professional education in music theory and composition in Saratov. He passed to his students his extensive knowledge, instilled in them love of art, developed the pedagogical traditions of his teachers, the great representatives of the Russian classical school, S.I. Taneyev and P.I. Tchaikovsky. Having not only a musical, but also a pedagogical talent, Leopold Moricevich quickly gained authority among both his students and his colleagues. In 1912, after the musical academy was transformed into the conservatory, L.M. Rudolf received the title of professor.

His main achievement was the organization of a systematical and serious teaching of musical theoretical subjects as a foundation for a professional musical education. From the very beginning of his pedagogical work in Saratov, he consistently improved the content and methodology of teaching theoretical courses, worked hard to raise the level of theoretical training of the graduates of the musical academy and the conservatory in all departments. Thanks to the Rudolf's efforts, the number of musicology students grew and their achievements became more prominent. For the first time there appeared composers among the graduates. In 1912, composers A. Zeider and I. Golikov graduated from the academy from the class of L.M. Rudolf, and in 1915 I. Golikov and I. Tulupnikov graduated from the conservatory.

At the Saratov conservatory, L.M. Rudolf taught hundreds of students with different major subjects. Some of them later became prominent composers and musicologists. Among them are composers Y.V. Kochurov, V.V. Pushkov, K.Y. Listov, Y.S. Soloduho, musicologists I.V. Sposobin, S.B. Maksimov, A.N. Dmitriev, V.P. Shokin, S.I. Levit, L.L. Kristiansen, I.A. Tyutmanov, Y.K. Evdokimov and many others. They respected their teacher deeply, admired his love of music, flexible mind, encyclopedic knowledge

Professor Rudolf's pedagogical method is brought to life with great clarity in the memoirs of A.N. Dmitriev ${ }^{6}$, one of his most talented students. He noted that Leopold Moricevich "told a lot about Taneyev, about his creative interests, his lessons, and his favorite works. In Rudolf's vivid and imaginative presentation, all this sounded extremely interesting, and through the stories about Taneyev, the image of P.I. Tchaikovsky also clearly shone through. As you know, among the

A.N. Dmitriev (1908 - 1978) was a musicologist, pianist, conductor, doctor of arts, and professor of the Leningrad N.A. Rimski-Korsakov Conservatory. He was born in Saratov and studied at the Saratov Conservatory as a pianist (under P.K. Pries) and a composer (under L.M. Rudolf), later at the Leningrad conservatory (under B.V. Asafiev). 
three greatest geniuses who were worshipped by both Taneyev and Tchaikovsky - Bach, Mozart, Beethoven - the first place in their deepest human sympathies belonged to Mozart. This composer was literally idolized by both Taneyev and Tchaikovsky. Of course, L.M. Rudolph shared the same sympathies and passed them on to us, his students. In addition to classes at the conservatory, to working out the necessary theoretical themes, Rudolf played a lot of various works (by the way, with me a quatre mains)" [1]

L.M. Rudolph was a talented composer, the author of cantatas for choir and symphony orchestra, chamber works, including two piano trios (d-moll and G-dur) and a g-moll string quartet. According to his contemporaries, the best works of L.M. Rudolph were romances with the lyrics of M.Y. Gordel. The composer also created piano pieces, works for violin and piano ("Elegy"), arrangements of Russian and Azerbaijan folk songs and other works. Many of them were published during the author's lifetime, but most of them, unfortunately, have not been preserved to our time. In his work, L.M. Rudolph developed the traditions of P.I. Tchaikovsky, S.I. Taneyev and other representatives of the Russian composition school. His music is coloured with lyric and dramatic tones. It is beautiful, expressive, full-blooded, characterized by whimsical colorfulness of the harmonic language, intensity of development, polyphonic thinking.

The works of L.M. Rudolph were often performed and enjoyed success with the public. For example, in March 1914, at the celebration of S.K. Eksner who left the office of the conservatory director in the Great Hall the singer Eichenvald-Dubovskaja performed L.M. Rudolf's romances with the lyrics of M.Y. Gordel accompanied by M.L. Presman. On 16 March 1917 at the "Evening of Freedom" dedicated to the day of the Paris Commune the "Anthem to the freedom fighters" with the lyrics of M.Y. Gordel evoked a hearty response from the audience. Performed by a symphonic orchestra and a choir, "it provoked recalls and a storm of applause. The author who conducted personally was presented with red flowers" [3]. This remark by N.F. Taube, an expert on the history of the Saratov Conservatory, paints vividly the atmosphere of the evening, the enthusiastic response of the audience inspired by the revolutionary ides of that time and their musical expression. Besides, it characterizes another important side of L.M. Rudolf's versatile activity - his conducting. He was known not only to conduct the performances of his own works, but also to act as an interpreter of the musical classics. This can be confirmed by the fact that among the big events in the concert life of the year 1912 many listeners remembered a symphony concert with works by Beethoven under his direction.
But perhaps the most significant and important event was the solemn concert to the opening of the Saratov Conservatory. Rudolf wrote for it a "Cantata to Honour of the Art of Music" with the words of a cellist M.Y. Gordel, another professor of the Conservatory and his constant collaborator. It was performed under Rudolf's direction and sounded as a grand anthem to music and beauty. However, the musical imagery of this short one-part work is ambiguous. The cantata begins with a rather somber opening theme, played by a French horn solo against a background of strings in the key of f, slowly, softly and sternly. This theme is extremely important for the whole subsequent development, because from its intonations, which connect the interrogative of the ascending quarto with the impotent chromatic descent and the general predominance of the descending movement, the entire thematic material of the cantata grows later, the character of which is gradually transformed accumulating energy, orientation upwards, rhythmic certainty and effectiveness. The tonal-modulatory development is very intense and reflects the movement from the mysterious twilight to light and joy, it covers a wide range of keys, forming several waves and gradually conquering new peaks, then again retreating into the shadow, finally leads to the affirmance of the radiant $\mathrm{F}$ major. This is how the composer expresses by means of musical language the idea of finding harmony, meaning and happiness in the pursuit of the beauty of an eternal art that gives strength to overcome life's adversities.

The author's manuscript of the score and orchestral parties of the cantata, stored in the archive of the conservatory library, was written, although with all care, but in pencil. Over time, it became unusable for the performing. In 2012, the composer V. S. Mishle edited and computer-typed the text of this remarkable score, which has become a precious historical document. On the eve of the 100th anniversary of the Saratov L.V. Sobinov Conservatory and the 135th anniversary of L.M. Rudolf's birth the cantata was published [4].

An integral part of L.M. Rudolph's life was musical educational work. He often gave lectures on music, opening remarks before concerts, addressing a wide variety of listeners, from students of the Conservatory and regulars of symphony concerts to students of the music academy and the public new to the art of music. There are many references to such addresses preserved. V.E. Khaneckiy tells how before the first concert of the string quartet of the Proletarian music school in the season 1922-23 L.M. Rudolf made an opening speech about the history of chamber music in general and specifics of a quartet as a genre [5]. A prominent event was the first conservatory student musical assembly dedicated to the works of J.S. Bach that was held on 13 December 1922. The newspaper "Saratovskie 
Izvestiya" wrote about it: "The aim of the assembly is the most possible artistic development of the students through acquainting them to the works of the great masters... An extensive program was preceded with an elaborate report on the life and works of J.S. Bach. A very active participant of this students' endeavor was Professor Rudolf' [5].

Leopold Moricevich's musical, social and organizational activities were very fruitful. He was a member of the Artistic Council of the Conservatory, represented it often in various public organizations, and actively participated in the creation of new music schools and institutions. So, in 1916 at the Society of People's Universities of Saratov on the initiative of the Conservatory professors L.M. Rudolph, B.K. Radugin, N.I. Speransky a music section was opened (with Rudolf as a chairman). It developed and implemented the creation of the People's Conservatory in Saratov to introduce music culture to the general population. This was of great importance for the democratization of music education in Saratov. L. M. Rudolph was unanimously elected as the head of the new educational institution and led it for more than ten years. The basis of the People's Conservatory were choral classes with a three-year course of study and mandatory study of elementary music theory and solfeggio. Later, piano classes were also opened, and later on the basis of the People's Conservatory a music school was formed and still exists today. L.M. Rudolph was not only its founder, but also its first director.

In the 20s, L. M. Rudolf belonged to a Board that directed the activity of the whole Saratov musical district consisting of five governments. He was a member of a musical-pedagogical section of the Department of Arts that presided over the work of all musical educational institutions in the city and the region and pursued preservation, protection and development of the musical culture.

L.M. Rudolf's contribution to the development of the Russian musical education and awareness was highly praised not only by his colleagues and numerous students, but also by the state. In 1922, he was awarded the title of the Hero of Labour. The honoring of the 47 awardees, among whom were other Conservatory professors M.E. Medvedev and G.K. Ershov, took place on 29 October and timed to the 250th anniversary of the Russian theatre.

On 1 March 1926, a festive concert dedicated to the 25 th anniversary of the scientific, pedagogical and creative activities of professor L.M. Rudolph was held. According to N.M. Tsyganova ${ }^{7}$, professors of the

N. M. Tsyganova is a pianist, the sister of D.M. Tsyganov, one of the first graduates of the Saratov Conservatory, who later devoted many years to teaching within its walls. She was the first head of the general piano department, Edited some of the L.M. Rudolf's works.
Conservatory M. I. Gelever, M. Gorodinsky, M.V. Tarotin, B.K. Radugin, A.M. Pashalova took part in this concert. D-moll String Quartet, d-moll trio for violin, cello and piano, b-moll polonaise for piano and romances "I created a whole moment", "My poor friend", "Lily of the Valley" were performed.

\section{SCIENTIFIC AND PEDAGOGICAL HERITAGE OF L.M. RUDOLPH}

Scholar work of L.M. Rudolf was a very important part of his many activities. As a respected theorist, he took part in editing the scientific legacy of his teacher, S.I. Taneyev His own extensive knowledge and longterm teaching experience Leopold Moricevich summarized in his research and methodological works. These include "The Manual for the Analysis of Musical forms" (Saratov, 1914) ${ }^{8}$; "Revision Exercises for the Piano Harmony" (Baku, 1936); "Harmony textbook. A Practical Course" (Baku, 1935, 1938), "Piano Harmony Exercises" (Baku, 1936, 1961, 1969). Nowadays these books are a bibliographic rarity, but they are of great interest both for teachers of theoretical musical subjects and everyone who is interested in the development of the Russian musicology and music pedagogy.

The Saratov conservatory library takes pride in having a "Manual for the Analysis of Musical Forms Complied for the Classes of the Saratov Alexey Conservatory by Professor L.M. Rudolf", published in Saratov in $1914^{9}$. It is one of the first textbooks of this kind in Russia [7]. I.A. Tyutmanov said about the value of this work: L.M. Rudolf "in a clear and accessible form briefly and thoughtfully describes the main types of polyphonic, homophonic and cyclic forms, in relation to the course called "encyclopedia of music" that existed at that time in the curriculum of the Conservatory. At the same time, the textbook contains a number of new elements, in comparison with the manuals of other authors that were used in the educational practice of that period. In particular, theoretical information about counterpoint and imitation-canonical forms reveals a direct connection with the ideas of S.I. Taneyev" [8].

It is well-known that in the period of its establishment the Russian analytic school was under

\footnotetext{
8 Now a reissue of this work is being prepared at the conservatory with the commentary by the art history $\mathrm{PhD}$, the assistant professor of the music theory and composition department E.V. Ponomareva

I.A. Tyutmanov, professor of the music theory and composition department of the Saratov conservatory, a Rudolf's student and the author of an essay "The music theory and composition department" written in 1961 to the conservatory's 50th anniversary, mentioned that "The Manual for the Analysis of Musical forms" was written before the conservatory opened, in 1911, when Rudolf was a teacher of the Saratov music academy [8]. N.M. Tsyganova evidenced the same [6].
} 
great influence of the German musical-theoretical tradition. It makes perfect sense that L.M. Rudolf's textbook is based on the systematic differentiation of musical forms from the books of A. Marx and L. Bussler. The terminology of elementary structure units (motif, period, move), the list of basic forms (from song to sonata) shows that. L.M. Rudolf didn't claim any scientific or methodologic novelty but insisted on the practical goal of his work. That makes so important the idea that this manual was to be used by the students under the supervision of the author himself.

In the preface to his work, the author emphasizes its practical purpose, points out that this is a summary of a training course that does not involve a lengthy presentation of the material.

All the training material is divided in the "Manual..." into 5 "sections", within which the most important topics are highlighted:

- Counterpoint (simple and complex);

- Polyphonic forms (canon and fugue);

- Homophonic forms (cadences, motif, phrase, sentence, period, extension and contraction; song form; variations; complex song; features of large musical forms (themes, move, coda); rondo form; sonata form; sonatina form);

- Cyclic forms (suite, sonata, cantata, oratorio, opera, cyclic dance forms);

- Classification of musical works (by composition of performers; by origin; by special purpose or place of performance; by internal content).

Each section is divided into paragraphs (total of 211) where definitions of certain concepts are formulated succinctly and clearly. There are many references to specific musical works, but there are no musical examples themselves (they were obviously published separately and, unfortunately, have not been preserved). The general narrative style is extremely strict, and even dry. In general, the book is a detailed encyclopedic guide to polyphony and analysis of musical works, provided with an index of terms and titles found in the text. All the more unexpected in this context is a rather lengthy discussion about "absolute" and program music that concludes the book (\$§ 204211). Here the author departs from the chosen style and allows himself to speak freely and picturesque. This fragment, which is a complete essay on program music, could equally be part of a scientific study on the psychology of musical perception (quite actual even today), and a wonderful introductory speech to a concert, which allows us to judge indirectly the skill of L.M. Rudolph as a lecturer who opened a beautiful and complex world of music to his listeners. The depth of thinking, the emotionality, the impeccable logic, the ability to speak simply about complex things are the qualities that should have distinguished L.M. Rudolf as a speaker.

Of great interest is the last section of the textbook, "Classification of musical works" that shows how the problem of form and genre was understood in the music theory at the beginning of the last century. An author's systematization of musical genres ("arts of music" in Rudolf's wording) grouped on the base of four criteria is presented. These criteria are "composition of instruments", "origin", "intention", "content" 10 . One should notice that long before the classifications of T.V. Popova, A.N. Sohor, V.A. Zukkerman etc such distinction of musical genres pre-existed the functional genre theory of E.V. Nazajkinskij where functions of different genres are summarized in the triad of "communicative, tectonic" and semantic functions [11]

He also paid a great attention to the theory and practice in the course of harmony. In 1921, he revised a short textbook written by him before the opening of the conservatory, added new information and musical examples, developed the most complex topics in detail, such as "Modulation", "Accidental dissonances (nonaccord sounds)". "Chromaticism". Later, L.M. Rudolph returned to his textbook for harmony repeatedly, changing and supplementing specific places and the general layout. The final version was published in 1938 in Baku, where the author worked in the last years of his life.

It is interesting that L.M. Rudolf did not settle upon completing this textbook, in 1921 he outlined a perspective plan for building a harmony course. The description of this plan consisting of seven sections and covering different areas of studying this subject we can find in a manuscript by I.A. Tyutmanov [8]. Each section was conceived as an independent part of the overall set of classes for a student. As a whole, this complex, according to Rudolf himself, should have become a "way to achieve complete, comprehensive and lively harmony education" [Ibid.]. He assumed a comprehensive coverage of all forms of educational work:

- Brief presentation of theory (textbook).

- Comments on the theoretical presentation.

- Harmonic education of hearing (manuscript 1928/29).

- Harmony for piano (Baku, 1936)

- Collection of tasks and exercises (1938).

- Harmonic analysis.

10 An analogy can be drawn to the genre classification of V.A. Zukkerman with question-critera where, by whom, whom for, what for is music performed [10]. 
- The modern harmony.

Unfortunately, we do not have exact information about how fully this plan was implemented, because not all of the listed training books were published, although they were written. But it is clear that the comprehensive course of harmony considered both theoretical and methodological problems of teaching, as evidenced by the cited by I.A. Tyutmanov preface from the textbook of the year 1921: "The theses making up the content of the part one find a broader development and perhaps a full scientific justification here (in part two), partly based on physics and partly on psychology. This part should make the first one suitable for self-education, as well as help a less experienced teacher to get on the right path. For this last purpose, it contains many instructions, pedagogical techniques and methods of apparent explanation, drawn by the author from his own long practice" [8].

The works of L.M. Rudolph were of great theoretical and practical significance for the development of methods of teaching musical theoretical subjects in our country. They were republished after the author's death ("Exercises in harmony at the piano", Baku, 1961).

\section{CONCLUSION}

Pedagogical, scientific, educational, organizational, musical and social, performing activities of L.M. Rudolph who, according to I.A. Tyutmanov, was "tireless and ardent enthusiast in the field of music education at all stages of its development" [8], was of great importance for the formation of the young Saratov Conservatory and for the development of the city's cultural life. It laid the foundation for the whole future work of the music theory and composition department, defined the style and methods of its work based on the high professionalism and loyalty to the traditions of the Russian music school. Students of L.M. Rudolph continued the traditions inherited by him from the giants of the Russian composing and music-pedagogical school - P.I. Tchaikovsky and S.I. Taneyev not only in Saratov, but also in different parts of our country including Moscow, Leningrad, and Baku, which made a great contribution to the development of the Russian music education as a whole.

\section{References}

[1] A.N. Dmitriev, Research, articles, observations, essays, Leningrad, Soviet composer, 1989, p. 197-198.

[2] V. E. Khaneckiy, Sounds no more..., a monograph. Ed. compiled by N.V. Korolevskaya. Saratov, the Saratov State L.B. Sobinov Conservatory, 2017, 658 p.

[3] N.F. Taube, History of the Saratov Conservatory, essay 1: 19121917, manuscript, p. 55
[4] L.M. Rudolf, Cantata for choir and orchestra, full score. Saratov, the Saratov State L.B. Sobinov Conservatory, 2017, 42 p.

[5] V.E. Hanetskij, the Musical life of Saratov. 1922-1923 years. A manuscript. Pp. 18, 14.

[6] Leopold Moricevich Rudolf in the memoirs of his students, collection of articles. Ed. - compiled by N.V. Ivanova. Saratov, the Saratov State L.V. Sobinov Conservatory 2012, p. 59.

[7] L.M. Rudolf, The Manual for the analysis of musical forms Saratov, Typo-lithography of partnership G. H. Shelgorn and Co, 1914. 65 p

[8] I.A. Tyutmanov, Department of theory and history of music, manuscript, pp. 5-6.

[9] A.S. Arenskiy, A Manual for studying form of instrumental and vocal music. Moscow, 1983.

[10] V.A. Zukkerman. Musical genres and basics of musical forms Moscow, 1964

[11] E.V. Nazaykinskiy. Style and genre in music. Moscow: Vlados, 2003. 